\title{
Endovascular treatment of Nutcracker syndrome
}

\section{Tratamento endovascular da sindrome de Quebra-nozes (Nutcracker)}

\author{
Jorge Ribeiro da Cunha Júnior ${ }^{1,2}$, Tiago Coutas de Souza², Adilson Toro Feitosa ${ }^{3}$ \\ José Ricardo Brizzí, Juliana Amaral Tinoco ${ }^{3}$
}

\begin{abstract}
Nutcracker syndrome refers to signs and symptoms secondary to compression of the left renal vein, most commonly between the superior mesenteric artery and the aorta, leading to impaired outflow to the vena cava. Diagnosis of this syndrome is often difficult and as result is late in most cases. We report on the case of a 51-year-old woman successfully treated with embolization of the ovarian vein and insertion of a self expandable stent in the left renal vein. Technical details and pitfalls are discussed.
\end{abstract}

Keywords: Nutcracker Syndrome; Nutcracker phenomenon; renal vein entrapment; Pelvic Congestion Syndrome.

\section{Resumo}

A Síndrome do Quebra-nozes se refere a um conjunto de sinais secundários à compressão da veia renal esquerda, mais comumente entre a artéria mesentérica superior e a aorta, levando ao comprometimento do fluxo para a veia cava. O diagnóstico desta síndrome frequentemente é difícil e, por esta razão, o diagnóstico é demorado, em muitos casos. É relatado, nesta publicação, o caso de uma mulher de 51 anos, tratada com sucesso pela embolização da veia ovariana associada ao implante de stent autoexpansível na veia renal esquerda. São discutidos os aspectos técnicos e as dificuldades do procedimento.

Palavras-chave: Síndrome do Quebra-nozes; fenômeno do Quebra-nozes; encarceramento da veia renal; Síndrome da Congestão Pélvica 


\section{INTRODUCTION}

Nutcracker syndrome describes a collection of signs and symptoms secondary to compression of the left renal vein. The most common location of compression is between the superior mesenteric artery and aorta. Clinical manifestations include hematuria combined with other signs and symptoms, such as lumbar or pelvic pain and pelvic varicocele or varicose veins ${ }^{1,2}$. It most often affects women aged 20 to $40^{3,4}$ and is one cause of chronic pelvic pain that is underdiagnosed by the medical community ${ }^{5}$.

Treatment of the syndrome was formerly restricted to conventional open surgery, but improved diagnostic imaging methods and the introduction of endovascular surgery have led to less invasive approaches. Conventional surgery involves procedures that are associated with increased morbidity, such as transposition of the renal vein, kidney autotransplantation and even nephrectomy ${ }^{6-8}$.

This case report describes a patient diagnosed with Nutcracker syndrome who was treated successfully by embolization of the ovarian vein and insertion of a stent in the left renal vein.

\section{CASE REPORT}

A 51-year-old, white, female patient from Rio de Janeiro presented with intermittent macroscopic hematuria and episodic flank, back and loin pain. The patient's previous medical history included dyslipidemia; irritable bowel; fibromyalgia, and herniated lumbar disc. She reported being a nonsmoker and having no drug allergies except for a strong nauseous reaction to Plasil (metoclopramide hydrochloride).

On physical examination she exhibited pain in reaction to palpation of the left iliac fossa, but without painful decompression. Diagnostic investigation was by tomography of the abdomen and pelvis, showing a narrowing of the caliber of the left renal vein between the aorta and the superior mesenteric artery (Figure 1).

The patient had been receiving clinical treatment for around 2 years, but without effective relief from her symptoms. In view of the persistent nature of the symptoms and diagnostic confirmation of the syndrome, a combination treatment was planned consisting of angioplasty of the left renal vein and embolization of the ovarian vein.

The procedure was conducted under spinal anesthesia with puncture of the right femoral vein and insertion of a short $6 \mathrm{~F}$ sheath, followed by selective catheterization of the left renal vein and the ovarian vein along a rigid guide wire. Preoperative phlebography showed the superior mesenteric artery pressing down on the left renal vein and significant dilation of the ovarian vein (Figures 2 and 3). The short sheath was changed for an $8 \mathrm{~F}$ long sheath and selective catheterization of ovarian vein was conducted preparatory to embolization with a Renegade ${ }^{\circledR}$ microcatheter and release four $12 \times 30 \mathrm{~mm}$ Interlock ${ }^{\circledR}$ springs, followed by infusion of $5 \mathrm{ml}$ of $3 \%$ polidocanol in a dense foam (Figure 4). A $16 \mathrm{~mm} \times 60 \mathrm{~mm}$ self-expanding Wallstent ${ }^{\circledR}$ was then implanted in the left renal vein and angioplasty conducted with a $12 \times 40 \mathrm{~mm}$ XXL balloon, taking care to maintain an anchorage area both proximally and distally, to avoid migration to the cava (Figure 5). Control phlebography showed that satisfactory correction of left renal vein compression and

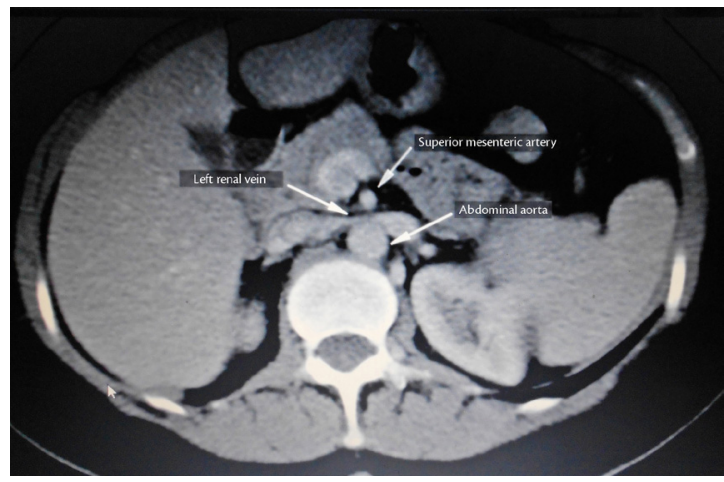

Figure 1. Angiotomography showing the left renal vein pinched by the superior mesenteric artery.

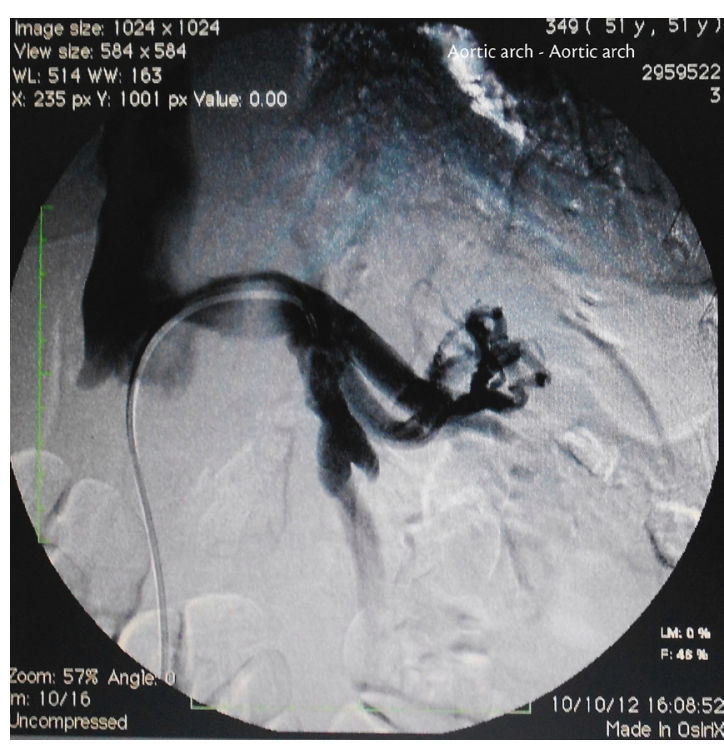

Figure 2. Phlebography showing dilatation of the ovarian vein. 


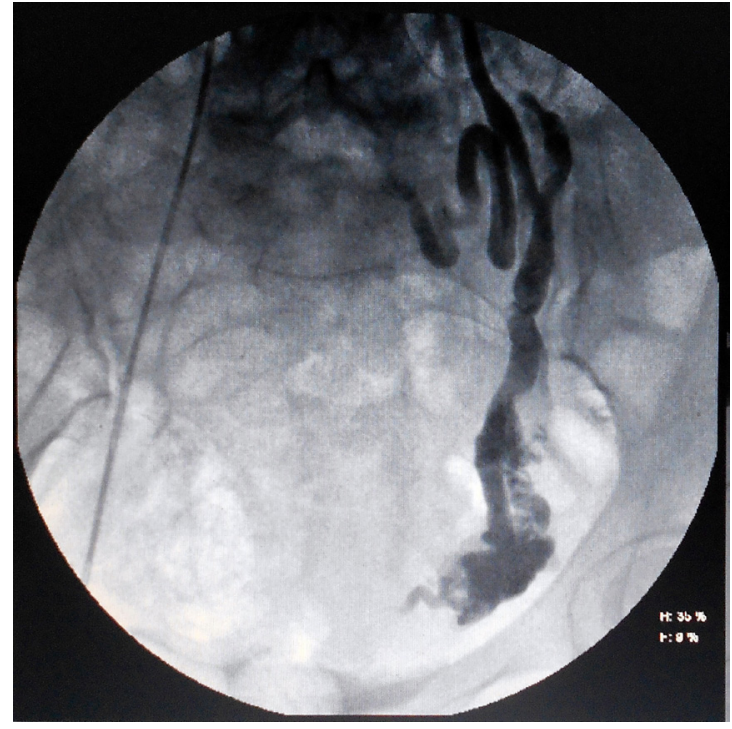

Figure 3. Phlebography showing dilatation of the ovarian vein.

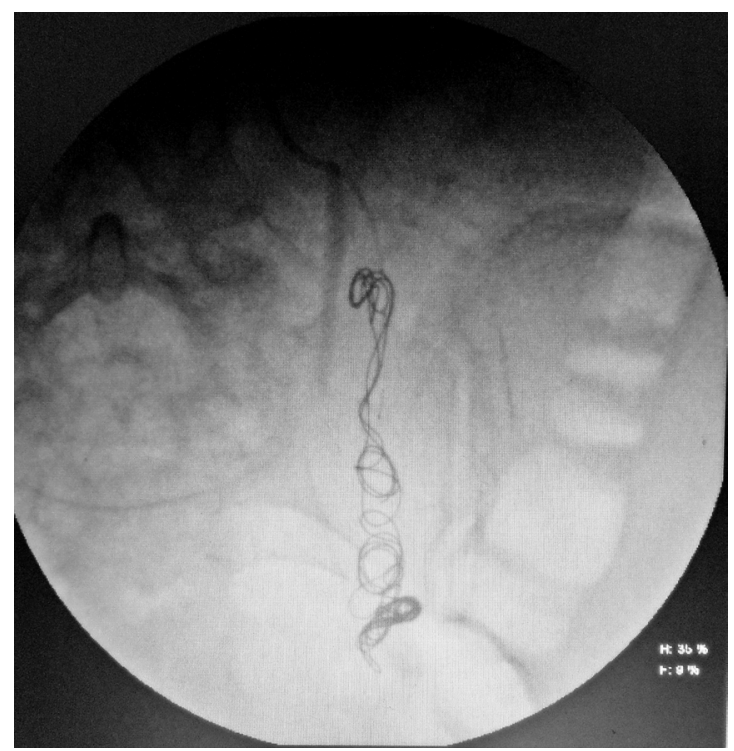

Figure 4. Implantation of the interlock springs and administration of $3 \%$ polidocanol to embolize the ovarian vein.

complete embolization of the ovarian vein had been achieved (Figure 6). The system was then removed and the puncture site compressed.

The patient progressed satisfactorily, with no intercurrent clinical conditions during the immediate postoperative period and was discharged 24 hours after the procedure, with a prescription for ASA $100 \mathrm{mg} 1 \times /$ day and clopidogrel $75 \mathrm{mg} 1 \times /$ day. Three months after the procedure, follow-up angiotomography was conducted and showed that the renal vein had been adequately decompressed (Figure 7). The patient is currently on ASA only.

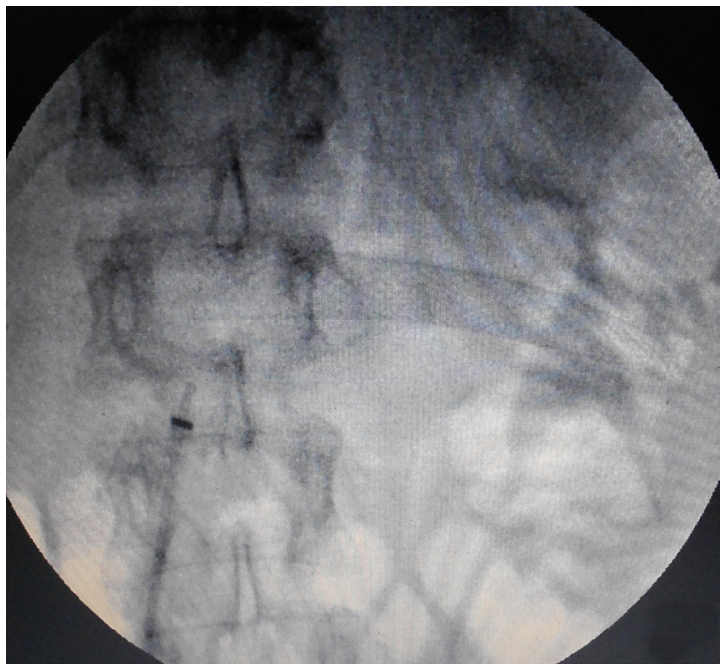

Figure 5. Placement of the stent in the left renal vein.

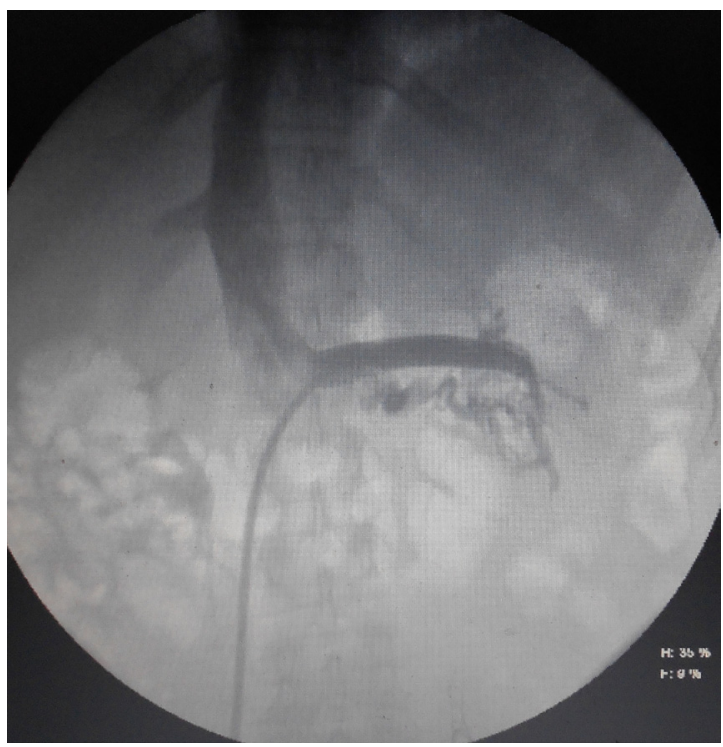

Figure 6. Postprocedural phlebography.

\section{DISCUSSION}

The first report of Nutcracker syndrome was published in 1950 by El-Sadr, who described compression of the left renal vein along its route between the abdominal aorta and the superior mesenteric artery. Compression was caused by a reduction in the angle between these two vessels and led to varying degrees of obstruction of left renal vein blood flow, causing venous hypertension ${ }^{2}$. In 1972, de Schepper named the condition Nutcracker syndrome ${ }^{1}$. The condition may present as an asymptomatic variant, but it can also cause significant 


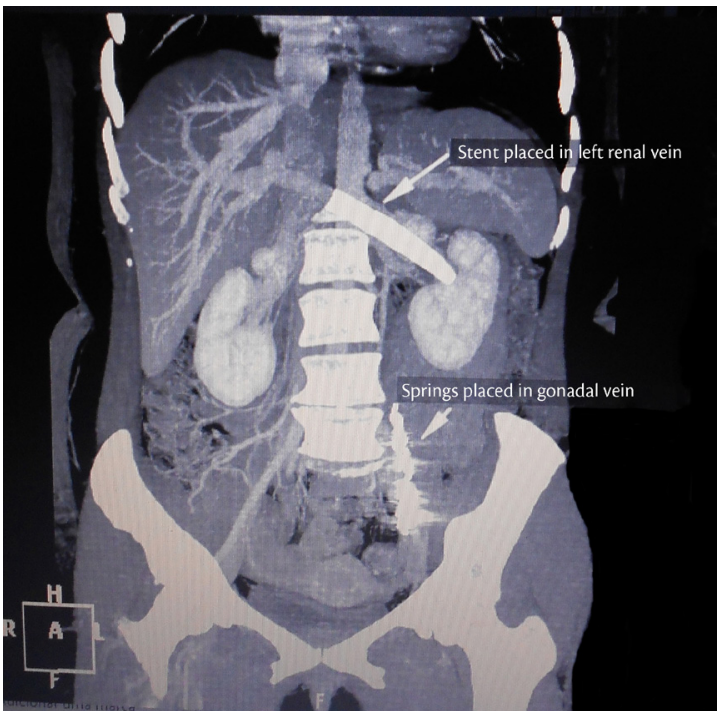

Figure 7. Follow-up angiotomography after 3 months. The large arrow indicates stent placement and the smaller arrow indicates placement of the springs.

clinical manifestations resulting from hypertension of the left renal vein, including hematuria, proteinuria, lumbar pain, left flank pain or hypogastric pain, and gonadal or periurethritic varicose veins, in young and previously healthy patients. Hematuria is the most common symptom, varying from microhematuria to profuse bleeding and anemia.

More rarely, there may be symptoms of pelvic congestion (dysmenorrhea, dyspareunia, pelvic pain and dysuria), the emergence of varicocele and varicose veins on the vulva, pelvis or gluteus, due to development of collateral circulation secondary to hypertension, particularly in adulthood ${ }^{9}$. Although prevalence is unknown, it appears to be greater among females and may have onset in childhood or adulthood, particularly between the ages of 10 and 30. Symptoms can be both intense and persistent and may worsen with physical activity.

Diagnosing Nutcracker syndrome can present a challenge since the same symptoms can be exhibited by more common clinical conditions, including kidney stones. Selective cystoscopy of the left urethral orifice showing hematuria in the absence of any other detectable disease should arouse suspicion of the syndrome ${ }^{10}$. In the case described here, this test was not conducted because hematuria was intermittent and in such cases it has low sensitivity ${ }^{10}$. Imaging exams, including vascular MRI, angiotomography, Doppler ultrasonography or even phlebography, are essential since they can reveal the compressive characteristic of the phenomenon $^{11,12}$, although diagnosis of the syndrome is based on the combination of symptoms and radiology findings.

Treatment of Nutcracker syndrome is debatable, but there are both clinical and surgical options, depending on the severity of the symptoms exhibited, i.e. the treatment of choice is intimately related to the severity of symptoms. Clinical treatment is indicated when symptoms are tolerable, such as mild hematuria and pelvic pain that can be controlled with analgesics ${ }^{13}$. Surgical treatment is indicated in cases with persistent hematuria associated with anemia, functional renal failure and uncontrolled pelvic pain, or if conservative treatment is ineffective after 2 years' clinical follow-up ${ }^{14-17}$. In the case described here, the patient had already been on clinical treatment for a long time, without effective control of the pelvic symptoms being achieved and with persistent intermittent hematuria.

The first description of a proposed surgical treatment for the syndrome was published by Pastershank ${ }^{18}$ in the 1970 s and since then variations in the renal vein transposition technique have been described and reported as being effective surgical solutions ${ }^{19}$. Autotransplantation of the kidney is a more invasive technique, but it can produce excellent results. Some authors believe that autotransplantation is the most effective treatment for resolution of symptoms, but it is associated with elevated morbidity and mortality rates.

Endovascular treatment of Nutcracker syndrome is a new tool for treating the syndrome offering the advantages of being less invasive and causing less morbidity and mortality. It was described for the first time in 1996 by Neste et al., in a study of 37 cases that had satisfactory outcomes, although the postoperative follow-period was short ${ }^{6}$. In 2011, Shanwen published a series of 61 patients operated using the endovascular technique and followed up for 66 months, observing satisfactory efficacy and low rates of both perioperative and postoperative complications ${ }^{7}$.

Over recent years, endovascular stent implantation techniques have been used to treat obstructive diseases of the venous system with satisfactory results, primarily because they are minimally invasive. There is not yet, however, consensus on their use to treat Nutcracker syndrome because there are no long-term follow-up studies in the literature. Notwithstanding, endovascular treatment may well become the option of choice for the syndrome in the near future. 


\section{REFERENCES}

1. De Schepper A. "Nutcracker" phenomenon of the renal vein and venous pathology of the left kidney. J Belge Radiol. 1972;55:50711. PMid: 4660828

2. El-Sadr AR, Mina E. Anatomical and surgical aspects in the operative management of varicocele. Urol Cutaneous Rev. 1950;54:257-62. PMid:15443180.

3. Kurklinsky A, Rooke T. Nutcracker Phenomenon and Nutcracker Syndrome. Mayo Clinic Proc. 2010; 85(6):552-9. PMid:20511485 PMCid:PMC2878259. http://dx.doi.org/10.4065/mcp.2009.0586

4. Ahmed K, Sampath R, Khan MS. Current Trends in the Diagnosis and Management of Renal Nutcracker Syndrome: A Review. Eur J Vasc Endovasc Surg. 2006;31:410-6. PMid:16431142. http://dx.doi. org/10.1016/j.ejvs.2005.05.045

5. Almeida R, Barros E, Balbinoto A, Thome F, Costa F. Síndrome de Nutcracker. Relato de Caso. Rev Bras Clin Med. 2010;8(3):283-5.

6. Neste MG, Narasimham DL, Belcher KK. Endovascular stent placement as a treatment for renal venous hypertension. J Vasc Interv Radiol. 1996;7:859. http://dx.doi.org/10.1016/ S1051-0443(96)70861-8

7. Chen S, Zhang H, Shi H, Tian L, Jin W, Li M. Endovascular Stenting for Treatment of Nutcracker Syndrome: Report of 61 Cases With Long-Term Followup. J Urol. 2011;186:570-5. PMid:21683388. http://dx.doi.org/10.1016/j.juro.2011.03.135

8. Wang X, Zhang Y, LiC, Zhang H. Results of endovascular treatment for patients with nutcracker syndrome. J Vasc Surg. 2012,56:142-8 PMid:22575480. http://dx.doi.org/10.1016/j.jvs.2012.01.007

9. Ferreira M, Lanziotti L, Abuhadba G, Monteiro M, Capotorto L, Spicacci JL. Dor pélvica crônica: o papel da síndrome do quebranozes. J Vasc Bras. 2008;7(1):76-9. http://dx.doi.org/10.1590/ S1677-54492008000100014

10. Zhang H, Zhang N, Li M, et al. Treatment of six cases of left renal nutcracker phenomenon: surgery and endografting. Chin Med J (Engl). 2003;116:1782-4.

11. Kim KW, Cho JY, Kim SH, et al. Diagnostic value of computed tomographic findings of nutcracker syndrome: Correlation with renal venography and renocaval pressure grandients. Eur J Radiol. 2011;80(3):648-54. PMid:20869828. http://dx.doi.org/10.1016/j. ejrad.2010.08.044

12. Silva M, Maurano A, Mendes G, et al. Síndrome de Nutcracker: a aplicação da ultra-sonografia com Doppler e relato de caso. Rev Imagem. 2007;29(3):121-4.

13. Dever DP, Ginsburg ME, Millet DJ, Feinstein MJ, Cockett ATK. Nutcracker phenomenon. Urology 1986;27:540-2. http://dx.doi. org/10.1016/0090-4295(86)90337-7

14. Stewart BH, Reiman G. Left renal venous hypertension "nutcracker" syndrome. Managed by direct renocaval reimplantation. Urology. 1982;20:365-9. http://dx.doi.org/10.1016/0090-4295(82)90457-5
15. Hohenfellner M, Steinbach F, Schultz-Lampel D, et al. The nutcracker syndrome: new aspects of pathophysiology, diagnosis and treatment. J Urol. 1991;146:685-8. PMid:1875472.

16. Hohenfellner M, D'Elia G, Hampel C, Dahms S, Thüroff JW. Transposition of the left renal vein for treatment of the nutcracker phenomenon: long-term follow-up. Urology. 2002;59:354-7. http://dx.doi.org/10.1016/S0090-4295(01)01537-0

17. Shokeir AA, el-Diasty TA, Ghoneim MA. The nutcracker syndrome: new methods of diagnosis and treatment. $\mathrm{Br} J$ Urol. 1994;74:139-43. PMid:7921927. http://dx.doi.org/10.1111/j.1464410X.1994.tb16574.X

18. Pastershank SP. Left renal vein obstruction by a superior mesenteric artery. J Can Assoc Radiol. 1974;25:52-4. PMid:4823206.

19. Reed NR, Kalra M, Bower TC, Vrtiska TJ, Ricotta JJ 2nd, Gloviczki P. Left renal vein transposition for nutcracker syndrome. J Vasc Surg. 2009;49:386-93. PMid:19216958. http://dx.doi.org/10.1016/j. jvs.2008.09.051

Correspondence Jorge Ribeiro da Cunha Júnior Hospital Municipal Souza Aguiar - Cirurgia Vascular Praça da República, 111 - Centro CEP 20211-351 - Rio de Janeiro (RJ), Brazil Fone: +55 (21) 78714356 E-mail: jorgercjunior@gmail.com

Author information JRC) is vascular surgeon at Hospital Municipal Souza Aguiar and at Hospital Universitário Clementino Fraga Filho (UFRJ). TCS is vascular surgeon at Hospital Universitário Clementino Fraga Filho (UFRI)

ATF, JRB and JAT are vascular surgeons, Empresa Varilaser.

Author's contributions Conception and design: JRC), TCS, ATF, JRB, JAT Analysis and interpretation: JRCJ, TCS, ATF, JRB, JAT

Data collection: TCS, ATF, JRB

Writing the article: JRC), TCS Critical revision of the article: JRCJ, TCS, ATF, JRB, JAT Final approval of the article*: JRC), TCS, ATF, JRB, JAT

Statistical analysis: N/A

Literature review: JAT, JRC), TCS

Overall responsibility: JRC), TCS, ATF, JRB, JAT Obtained funding: None.

*All authors should have read and approved of the final version of the article submitted to J Vasc Bras. 